\title{
Needs Assessment to Develop Online Counseling Program
}

\author{
Phamornpun Yurayat ${ }^{1} \&$ Thapanee Seechaliao ${ }^{2}$ \\ ${ }^{1}$ Department of Educational Psychology and Guidance, Faculty of Education, Mahasarakham University, \\ Mahasarakham, Thailand \\ ${ }^{2}$ Department of Educational Technology and Communications, Faculty of Education, Mahasarakham University, \\ Mahasarakham, Thailand \\ Correspondence: Thapanee Seechaliao, Department of Educational Technology and Communications, Faculty of \\ Education, Mahasarakham University, Mahasarakham, Thailand. E-mail: thapanee.see@msu.ac.th
}

Received: February 5, 2021

Accepted: April 6, $2021 \quad$ Online Published: June 24, 2021

doi:10.5539/ies.v14n7p59

URL: https://doi.org/10.5539/ies.v14n7p59

\begin{abstract}
Undergraduate students are always faced with diverse mental health problems. Nowadays, they can easily access online counseling services to reduce their problems. This research determines the most desired component to develop the online counseling program which aims 1) to study the needs to develop an online counseling program, 2) to compare the needs to develop this program by categorizing with gender, year, academic program, and grade point average (GPA), and 3) to rank the priority needs for developing this program. Participants were 416 undergraduate students who studied in Mahasarakham University and were selected by stratified random sampling. The research instrument was the needs assessment questionnaire to develop this program. The data were analyzed using percentage (\%), mean (M), standard deviation (S.D.), independent sample t-test, one-way ANOVA, and modified priority needs index ( $\left.\mathrm{PNI}_{\text {Modified }}\right)$. The results revealed that: 1$)$ the mean of actual condition was at a high level $(\mathrm{M}=3.76$, S.D. $=0.59)$ and the mean of the desired condition was at the highest level $(\mathrm{M}=4.50$, S.D. $=$ 0.56) with the significant difference at 0.05 level in all four domains. 2) Undergraduate students from different academic programs exhibited the marked different means of needs for the online counseling program. The scores on actual conditions among students of Mahasarakham Business School were higher than students from others. 3) Students showed the highest priority needs on characteristics of counselor and online application for counseling $\left(\mathrm{PNI}_{\text {Modified }}=0.203\right)$. They showed that the secondary needs on characteristics of online counselee $\left(\mathrm{PNI}_{\mathrm{Modified}}=\right.$ $0.192)$ and therapeutic relationship after online counseling $\left(\mathrm{PNI}_{\text {Modified }}=0.177\right)$.
\end{abstract}

Keywords: needs assessment, online counseling service, online counseling program, undergraduate students

\section{Introduction}

\subsection{Background}

University life is the key stage of human development and turning point, transitioning from adolescence to adulthood (Arnett, 2004). Although this period is known for positive self-development (Evans, Forney, Guido, Patton, \& Renn, 2009), the university studying phase has been identified with the highest level of incidence in mental health illnesses (Ibrahim, Kelly, Adams, \& Glazebrook, 2013). Research findings have demonstrated that there are university students approximately 12 to $46 \%$ are affected by mental illnesses at any level (Auerbach et al., 2016; Auerbach et al., 2018; Eisenberg, Golberstein, \& Hunt, 2009; Verger, Guagliardo, Gilbert, Rouillon, \& Kovess-Masfety, 2009). Psychiatric problems account for half of the disease incidence among adolescents and young adults in high-income countries (World Health Organization [WHO], 2008), and they are correlated with long-term negative effects on individuals, including poor academic performance (Eisenberg et al., 2009) dropping out of university (Ishii et al., 2018) and poor daily living in the later stage of life (Goldman-Mellor et al., 2014; Niederkrotenthaler et al., 2014). Even though the universities are ready with effective therapeutic strategies, research studies have identified the major gap in treatment intervention among students suffering from mental health problems. Indeed, 1 in 5 students undergoes the least suitable treatment (Auerbach et al., 2016). On average duration, the untreated mental illnesses exert an ongoing impact on individuals further approximately 4 to 23 years (Wang et al., 2005) and an association with the worsening outcome of therapeutic treatment (Cheung, O'Donnell, Madi, \& Goldner, 2017). Therefore, the accessibility of mental health counseling services is essential to undergraduate students. 
Although most universities provide many counseling service centers to assist students, the number of clients at mental health counseling services is notably small. Hyun, Quinn, Madon, and Lustig (2006) have found that 70\% of university students are less likely to attend mental health counseling services. Undoubtedly, there are several crucial factors that students decide not to use the service at the university counseling center. First, undergraduate students are hesitated to make an appointment for face to face counseling service, which is a traditional method. Particularly, in Asian cultures, students feel ashamed about mental illnesses; therefore, they are afraid to ask mental health professionals for help (Al-krenawi, Graham, Al-bedah, Kadri, \& Sehwail, 2009; Heflinger \& Hinshaw, 2010). Seechaliao and Rungrueng (2016) described that undergraduate students who studied in Mahasarakham University always faced many mental health problems such as relationships, family issues, or academic problems. Although mental health services in the counseling center were provided to lecturers, students, staffs, and those who need such services, most undergraduate students rarely used these services at the counseling center because disclosing their identities may make them psychotic patients from others. Many undergraduate students tried to solve their mental health problems by consulting close friends or parents. Other factors include the traveling distance to the counseling center and the negative attitude from society towards individuals seeking mental health treatment, for instance (Fishbein \& Ajzen, 2000; Al-Krenawi \& Graham, 2000).

Social networking service has influenced people's lives throughout the world. Specifically, it exerts an enormous impact on teenagers and university students. In Thailand, there were social network users approximately 52 million people in January 2020.75\% of the population showed social media accessibility (Hootsuite \& We Are Social, 2020). Students are the most internet users who used approximately 10 hours and 50 minutes per day (Office of Policy and Strategic Affairs, Electronic Transactions Development Agency, Ministry of Digital Economy and Society, 2020). The rapid growth of internet technology leads to significant changes in human behaviors that can have consequential effects on mental health conditions (Sukmawati, Ardi, Ifdil, \& Zikra, 2019). Seechaliao and Rungrueng (2016) described that undergraduate students deemed that social media was one of the best communication channels to reduce their mental health problems. Social media such as YouTube, Facebook, and blogs were easy to use for communication with others and could serve as effective, supportive tools to create a mental health problem-solving community for learners, psychotic patients, counselors, and others who are related to this field or issue. They could learn how to solve problems, seek help with their problems, apply and try to solve their problems by themselves based on what they learned in social media. Two to three years ago, the effectiveness of internet technology in assisting and remediating mental health problems among university students has recently started to become clearer (Davies, Morriss, \& Glazebrook, 2014; Ebert, Cuijpers, Muñoz, \& Baumeister, 2017). Students can access the mental health service very easily without disclosing their legal names through the internet. Additionally, an online platform displays more effectiveness and high flexibility (Ebert et al., 2017). In 2011, the Royal College of Psychiatrists suggested universities should increase the preparedness of online mental health assistance for university students by using evidence-based internet intervention (Royal College of Psychiatrists, 2011). From the statistics of increasing internet accessibility and easily achievable manner, there is an expansion in mental health services through electronics (e-mental) worldwide. The goal of e-mental is to eliminate the obstacles in treatment intervention (Navarro, Bambling, Sheffield, \& Edirippulige, 2019).

Online counseling is the initial psychological counseling for individuals with mental health problems. Psychologists and mental health experts are people who give the service without meeting in person by using the internet system of information technology, for example writing an electronic mail (E-mail), talking via chat room, and video conferencing (Mallen \& Vogel, 2005). Thus, the counselors and the clients (or counselees) are in two different places, and they communicate with each other through the internet (Richards \& Viganó, 2013; Zainudin \& Yusof, 2018). There are several reasons that the clients choose to use online counseling services. First, clients live in remote areas. Second, clients may have difficulty with transportation. Third, the clients are unable to leave their houses because they may have household obligations, such as taking care of small children, elders, and other family members with disabilities. Fourth, it is impossible to change their work schedules for the counseling session. Or, some people may have frequent work-related traveling schedules. In addition, an online counseling platform is helpful for individuals with hearing loss and immobility. There are also several reasons why the counselors choose to give an online counseling session. For example, they can manage their flexible time and place to give a counseling session, and they can manage with the limitation on traveling (Jones \& Stokes, 2009). In the present day, access to online counseling services can be easily done as long as there is an internet platform for counseling sessions between the counselor and counselee (Zainudin \& Yusof, 2018). The number of research studies on online mental health assistance has increased because of its useful benefits (Mitchell, Vella-Brodrick, \& Klein, 2010). For online counseling clients, the assistance can be easily accessible 
because it does not adhere to specific places and fixed schedules. The information will also be kept confidential without revealing the clients' names. Additionally, therapeutic assistance is at a low cost (Bolier et al., 2014; Centore \& Milacci, 2008; Rodda, 2017). Furthermore, the treatment intervention can be adapted for each online counselee, such as suggestion and follow-up for a specific individual. In addition, mental health counselors can benefit from online services by implementing the same standard of mental health assistance. For example, the mental health information should be in the same context for everyone in order to reduce the miscommunication between the counselor and counselee (Gander, 2017).

According to the online mental health service in Thailand, the Department of Mental Health, Ministry of Public Health provides an internet-based mental health service with the use of chatroom through the MSN program. It is the channel for providing mental health services to general people. The open registration can be completed through an e-mail address: counseling_sty@hotmail.com. The counselees include small children, teenagers, and adults (Department of Mental Health, 2008). Moreover, some counseling psychologists have applied the internet as a way for psychological counseling service, known as online counseling. Chat-based online counseling allows the counseling psychologists to talk with the counselee through typing synchronous messages in real-time without meeting in person. This type of online counseling has been implemented for adolescents and young adults, such as university students (Vongtangswad, 2016). The outcome indicates the effectiveness of online counseling, showing its beneficial impact on daily problem-solving skills among students (Tannous, 2017).

In Thailand, the relevant literature reviews and the researchers have shown that there are very few studies on the needs assessment of online counseling among university students. The needs assessment is the procedure to evaluate the gap between "actual conditions" and "desired conditions" of things or places, which are subjected to study (Watkins, Meiers, \& Visser, 2012). The scopes of these studies show the diversity. Some studies focus on the analysis of needs assessment and the solution to the needs. Investigators may analyze the needs to reveal the cause of the needs and make the decision for the potential solution to the needs (Watkins \& Kaufman, 1996). According to the relevant research works' synthesis, the researchers have demonstrated four components of online counseling, including 1) characteristics of counselor for online counseling, 2) characteristics on counselees or clients, 3) online application system for counseling, and 4) therapeutic relationship of online counseling (Amichai-Hamburger, 2017; Barak, Klein, \& Proudfoot, 2009; S. Bastemur \& E. Bastemur, 2015; Cipolletta \& Mocellin, 2018; Colbow, 2013; Fenichel et al., 2002; Guay et al., 2017; Harris \& Birnbaum, 2015; Lindinger-Sternart \& Piazza, 2014; Liu, 2015; Mendes-Santos, Weiderpass, Santana, \& Andersson, 2019; Muir et al., 2020; Proudfoot et al., 2011; Richards \& Viganó, 2013; Ritterband, Thorndike, Cox, Kovatchev, \& Gonder-Frederick, 2009; Stoll, Müller, \& Trachsel, 2020; Teh, Acosta, Hechanova, Garabiles, \& Alianan Jr, 2014; Teo, Shi, Huang, \& Hoi, 2020). This study emphasizes these four components as research domains for needs assessment among undergraduate students of Mahasarakham University. The main goal is to determine which domain is the most desired component in the establishment of the online counseling program. Then, the research results would be used as principal criteria to meet the needs of undergraduate students and plan the guidelines for the development and implementation of online counseling. Furthermore, internet access is widely available to many people in the digital age; consequently, university students can easily access online counseling services. The application of internet technology for online mental health counseling services has recently been becoming popular that would be designed. It could be leading to an increase in student's wellness, reduced mental health problems, and behavioral adaptability to changes in the future.

\subsection{Purpose of the Study}

This research study aims 1) to investigate the actual and desired conditions of online counseling program among undergraduate students at Mahasarakham University, 2) to compare the needs for the development of online counseling program among undergraduate students by emphasizing gender, year, academic program, and GPA, and 3) to rank the priority needs for an implementation of online counseling program among undergraduate students.

\section{Method}

The research study focuses on the needs assessment to develop an online counseling program for undergraduate students of Mahasarakham University.

\subsection{Participants}

The population used in this research study consisted of 36,579 undergraduate students from Mahasarakham University, enrolling in the Academic Year 2020 from 18 faculties and 2 colleges. A total of 416 students was selected as participants using Yamane's Sampling Method (Yamane, 1967), with a 95\% confidence level and a proportion of allowable error of 5\%. Stratified random sampling was used for three groups, including 1) 
Humanities and Social Sciences, 2) Applied Sciences and Technologies, and 3) Health Sciences, providing more comprehensive and complete information on the characteristics of the sub-group. Additionally, simple random sampling was carried out by a random drawing generator so that every sub-sample group had an equal chance to be selected from 3 faculties that were from Humanities and Social Sciences, 2 faculties from Applied Sciences and Technologies, and 1 faculty from Health Sciences. Then, the rule of three in arithmetic was performed to calculate the number of samples in each faculty, according to the specified proportion.

\subsection{Variables}

The independent variables were identified as the gender, year, academic program, and GPA. The dependent variables were: 1) needs assessment to develop online counseling program of undergraduate students of Mahasarakham University, and 2) the priority of needs to implement online counseling program to undergraduate students.

\subsection{Research Instrument}

The research instrument was a questionnaire that was constructed to assess the needs for developing an online counseling program for undergraduate students of Mahasarakham University. The questionnaire was divided into two parts: 1) the demographic information of respondents and the needs assessment. 2) the 40-item needs assessment in a dual response format contained both actual and desired conditions of the online counseling program. The respondents indicated their actual or desired conditions on a five-level rating scale. The content validity was measured with an IOC value between $0.67-1.00$, and reliability was tested with a Cranach's alpha coefficient of 0.96 .

\subsection{Data Collection}

The participants were clearly explained about the details of research objectives and procedures for data collection. The informed consent forms were obtained, and the participants were asked to complete the questionnaires by our researchers, visiting each specified faculty. The completeness of questionnaires was checked for all answers. Data obtained from questionnaires were further analyzed.

\subsection{Data Analysis}

Descriptive statistics were applied, for example, percentage (\%), mean $(\overline{\mathrm{X}})$, and standard deviation (S.D.). The independent sample t-test and one-way ANOVA were also used to compare between the actual and desired conditions and to compare groups by gender, year, academic program, and GPA. Additionally, the ranking of needs in this research was performed using the modified Priority Needs Index ( $\left.\mathrm{PNI}_{\text {Modified }}\right)$ (Wongwanich, 2005; Wiratchai, 2005). It was used to describe the gap between the actual situation of university mental health counseling services and the criteria of online counseling programs to reach the desirable program for university students. Therefore, the needs were assessed to determine the differential values between desired condition (I) and actual condition (D), measuring the needs at the real level (Wongwanich, 2005). The formula for the calculation is as follows:

\section{$\mathrm{PNI}_{\text {Modified }}=$ Modified Priority Needs Index}

$\mathrm{PNI}_{\text {Modified }}=(\mathrm{I}-\mathrm{D}) / \mathrm{D}$

$\mathrm{I}=\quad$ Mean of the desired condition of an online mental health counseling of Mahasarakham University students

$\mathrm{D}=\quad$ Mean of the actual condition of an online mental health counseling of Mahasarakham University students

\subsection{Ethical Considerations}

This research study was approved by the Human Research Ethics Committee of Mahasarakham University (No. 228/2020), issued on 18 September 2020. All data were kept confidential.

\section{Results}

These research results were divided into 4 parts as follows:

\subsection{Demographic Data Regarding the Participants}

The participants comprised 416 undergraduate students of Mahasarakham University. Most of the respondents were female students (70.4\%), second-year students (32.5\%), the Mahasarakham Business School (38.2\%), and GPA of 2.51-3.00 (32.7\%). 
3.2 Analysis of Actual and Desired Conditions of Online Counseling Program Among Undergraduate Students of Mahasarakham University

Table 1. Comparison between actual and desired conditions of four domains in order to develop online counseling program for undergraduate students

\begin{tabular}{|c|c|c|c|c|c|c|c|c|}
\hline \multirow{2}{*}{ Online Counseling } & \multicolumn{3}{|c|}{ Actual Condition } & \multicolumn{3}{|c|}{ Desired Condition } & \multirow{2}{*}{ t-test } & \multirow{2}{*}{ Sig* } \\
\hline & $M$ & S.D. & Level & $M$ & S.D. & Level & & \\
\hline Characteristics of counselor & 3.75 & .63 & High & 4.51 & .56 & Highest & $23.91 *$ & .00 \\
\hline Characteristics of counselee & 3.75 & .66 & High & 4.47 & .60 & High & $22.22 *$ & .00 \\
\hline Online application & 3.74 & .68 & High & 4.50 & .61 & Highest & $22.79^{*}$ & .00 \\
\hline Therapeutic relationship & 3.84 & .69 & High & 4.52 & .61 & Highest & $20.23 *$ & .00 \\
\hline Total & 3.76 & .59 & High & 4.50 & .56 & Highest & $25.75^{*}$ & .00 \\
\hline
\end{tabular}

Note. ${ }^{*} \mathrm{P}<0.05 ; \mathrm{M}=$ Mean; S.D. $=$ Standard Deviation; $\mathrm{t}$-test $=$ The independent sample; Sig $=$ significant.

Table 1, the undergraduate students indicated that the overall online counseling program was at high level in actual condition $(M=3.76$, S.D. $=.59)$, with the mean scores of four domains ranked in descending order as follows: the therapeutic relationship $(M=3.84$, S.D. $=.69)$, the characteristics of counselor $(M=3.75$, S.D. $=.63)$, the characteristics of counselee $(M=3.75$, S.D. $=.66)$, and online application for online counseling $(\mathrm{M}=$ 3.74 , S.D. $=.68$ ), and respectively.

Furthermore, they exhibited the overall online counseling program at the highest level in desired condition $(M=$ 4.50, S.D. $=.56$ ), with mean scores of four domains ranked in descending order as follows: the therapeutic relationship $(M=4.52$, S.D. $=.61)$, the characteristics of counselor $(M=4.51$, S.D. $=.56)$, online application for online counseling $(M=4.50$, S.D. $=.61)$, the characteristics of counselee $M=4.47$, S.D. $=.60)$, respectively. Details are shown in Figure 1.

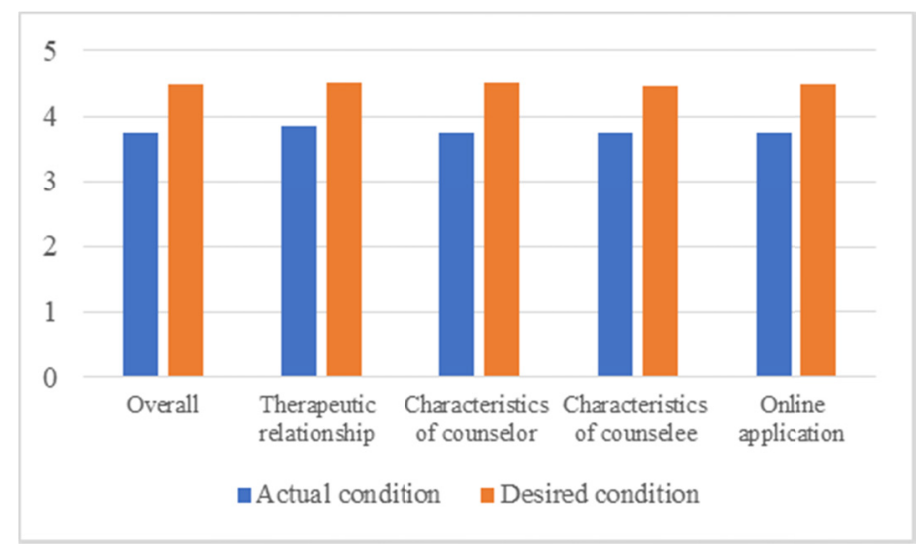

Figure 1. Comparison between actual and desired conditions of four domains

Accordingly, the average scores of four domains showed the significant difference between the actual and desired conditions. The actual condition exhibited lower scores than the desired condition in all aspects, reflecting the needs to an develop online mental health counseling program among undergraduate students. 
3.3 Comparison of the Needs to develop the Online Counseling Program Among Undergraduate Students by Gender, Year, Faculty, and Academic Achievement

Table 2. Comparison of the actual condition of an online counseling program by gender, year, faculty, and GPA

\begin{tabular}{|c|c|c|c|c|c|c|c|}
\hline \multicolumn{2}{|c|}{ Personal Factor } & \multirow{2}{*}{$\begin{array}{c}M \\
3.65\end{array}$} & \multirow{2}{*}{$\frac{\text { S.D. }}{.65}$} & \multirow{2}{*}{$\frac{\mathrm{t}}{2.14}$} & \multirow{2}{*}{$\begin{array}{c}\text { Sig* } \\
.36\end{array}$} & & \multirow{3}{*}{ There is no significant difference. } \\
\hline \multirow{2}{*}{ Gender } & Male & & & & & & \\
\hline & Female & 3.79 & .62 & & & & \\
\hline \multicolumn{2}{|c|}{ Source of Variation } & SS & $\mathrm{df}$ & MS & $\mathrm{F}$ & Sig* & Pairwise Comparison \\
\hline \multirow{3}{*}{$\begin{array}{c}\text { Academic } \\
\text { Year }\end{array}$} & $\begin{array}{c}\text { Between } \\
\text { Groups }\end{array}$ & 1.56 & 4 & .389 & 1.10 & .353 & \multirow{3}{*}{ There is no significant difference. } \\
\hline & $\begin{array}{l}\text { Within } \\
\text { Groups }\end{array}$ & 144.50 & 411 & .352 & & & \\
\hline & Total & 146.05 & 415 & & & & \\
\hline \multirow{3}{*}{ Faculty } & $\begin{array}{c}\text { Between } \\
\text { Groups }\end{array}$ & 5.59 & 5 & 1.12 & $3.26^{*}$ & $.007 *$ & \multirow{3}{*}{$\begin{array}{l}\text { The significant difference between five groups, including } \\
\text { Mahasarakham Business School }>\text { Faculty of Engineering, } \\
\text { Mahasarakham Business School }>\text { College of Politics and Governance } \\
\text { Faculty of Science }>\text { Faculty of Engineering, Faculty of Education }> \\
\text { Faculty of Engineering, and Faculty of Education }>\text { College of Politics } \\
\text { and Governance }\end{array}$} \\
\hline & $\begin{array}{l}\text { Within } \\
\text { Groups }\end{array}$ & 140.46 & 410 & .34 & & & \\
\hline & Total & 146.05 & 415 & & & & \\
\hline \multirow{3}{*}{ GPA } & $\begin{array}{c}\text { Between } \\
\text { Groups }\end{array}$ & 2.68 & 4 & .669 & 1.91 & .107 & \multirow{3}{*}{ There is no significant difference. } \\
\hline & $\begin{array}{l}\text { Within } \\
\text { Groups }\end{array}$ & 143.38 & 411 & \multirow[t]{2}{*}{.349} & & & \\
\hline & Total & 146.05 & 415 & & & & \\
\hline
\end{tabular}

Table 2, the results illustrated that only undergraduate students from different faculties showed the statistically significant difference in the mean scores on the actual condition of the online counseling program at the .05 level.

\subsection{Ranking of the Needs to Develop an Online Counseling Program Among Undergraduate Students}

Table 3. Analysis of the modified Priority Needs Index ( $\left.\mathrm{PNI}_{\text {Modified }}\right)$

\begin{tabular}{lcccc}
\hline Online Counseling & Mean of actual condition (D) & Mean of desired condition (I) & $\begin{array}{c}\text { PNI }_{\text {Modified }} \\
\text { (D-I)/D }\end{array}$ & Rank \\
\hline Characteristics of counselor & 3.75 & 4.51 & .203 & 1 \\
Characteristics of counselee & 3.75 & 4.47 & .192 & 2 \\
Online application & 3.74 & 4.50 & .203 & 1 \\
Therapeutic relationship & 3.84 & 4.52 & .177 & 3 \\
Total & 3.76 & 4.50 & .197 & \\
\hline
\end{tabular}

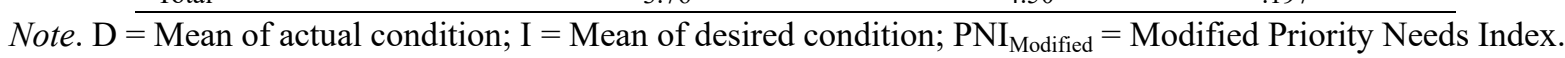

Table 3 illustrated that the modified Priority Needs Index ( $\mathrm{PNI}_{\text {Modified }}$ ) of four components contained values ranging from 0.177 to 0.203 . The priorities of needs were ranked in descending order as follows: 1) characteristics of counselor $\left(\mathrm{D}=3.75, \mathrm{I}=4.51 ; \mathrm{PNI}_{\text {Modified }}=0.203\right)$ and online application $(\mathrm{D}=3.74, \mathrm{I}=4.50$; $\left.\left.\mathrm{PNI}_{\text {Modified }}=0.203\right), 2\right)$ characteristics of counselee $\left(\mathrm{D}=3.75, \mathrm{I}=4.47 ; \mathrm{PNI}_{\text {Modified }}=0.192\right)$, and 3$)$ therapeutic relationship $\left(\mathrm{D}=3.84, \mathrm{I}=4.52\right.$; $\left.\mathrm{PNI}_{\text {Modified }}=0.177\right)$. The prioritization of needs is useful for guiding in the development of online counseling program for undergraduate students of Mahasarakham University.

\section{Discussion}

This research results showed some key important aspects that could lead to the effective development of mental health counseling using the online platform. We separated our discussion in accordance with the research 
objectives as follows.

\subsection{Needs for Development of Online Counseling Program to Undergraduate Students of Mahasarakham University}

According to the collecting data, we discovered that our students showed the needs to develop and online counseling program in all four aspects, including the criteria for choosing a counselor, how to effectively operate an online platform, a background of the counselee, and therapeutic effects of the online counseling program. By assessing the needs for online counseling services, both actual and desired conditions were considered. The therapeutic relationship of online counseling showed the highest mean scores for the needs. Indeed, the counseling is the relational process of two-way communication between the counselor and counselee. The counselor acquires professional expertise through both knowledge and practical skill-based training to assist the clients (or counselees) so that they become aware of their thinking, emotion, behavior, and meaning of life. The counselees can further understand their mind-related problems and anxiety and find the solution to solve those problems with their potentials. Subsequently, they can apply their new understandings to effectively live their lives with happiness (Yurayat, 2020). Therefore, the therapeutic relationship is the most important factor among intratherapeutic factors, and it has a crucial effect on treatment intervention (Lamber \& Barley, 2001). Empirical research studies have shown that individual counseling or face-to-face therapy exerts its effectiveness on therapeutic intervention and positive relationship between counselor and counselee (Krupnick et al., 1996; Martin, Garske, \& Davis, 2000). However, the previous research has shown that some students state that online counseling relationships are shallow, impersonal, and unreal (Slouka, 1995). The online counselees feel dissatisfied with the online relationship including the self-disclosure on an online platform and the feelings of closeness between counselor and counselee whenever they compared to individual counseling (Mallen, Day, \& Green, 2003). Additionally, the limitation of online counseling could be that the counselor might have difficulty understanding the counselee's true feelings (Fusikul, 2012), the negative result effects on interaction towards counselee (Li, Jaladin, \& Abdullah, 2013). On the contrary, other previous researches have demonstrated that some online counseling clients give a very high score on the relationship building between counselor and counselee. Subsequently, this outcome indicates that it's possible to establish a stable and positive therapeutic relationship in online counseling (Knaevelsrud \& Maercker, 2006). For the most part, many previous studies have reported that online counselees exhibit a positive attitude towards online counseling that is a major benefit. Students from Trinity College Dublin (TCD) stated that online counseling was very worthwhile for them (Richards \& Tangney, 2008). Moreover, online counseling and face to face counseling can be co-implemented for the increase in the effectiveness of counseling processes (Teh et al., 2014).

\subsection{Students' Perspectives of the Actual Condition of Online Counseling Program by Gender, Year, Faculty, and GPA.}

The participants in this study showed diverse views on the establishment of an online counseling program in accordance with their academic backgrounds. The results indicated that students from different academic faculties exhibited significantly different aspects of needs for online counseling programs in actual condition. This could be that Mahasarakham University contains a number of mental health counseling clinics, including the Counseling Center of Student Affairs Division, Center of Excellence in Psychology of Faculty of Education, Mental Health Counseling Clinic of Faculty of Nursing, and Mental Health Clinic of Suddhavej Hospital. Therefore, undergraduate students of these faculties can easier access mental health counseling services than students from other academic institutes. In addition, each academic faculty has its policy and management; thus, it places the different emphasis on mental health counseling. The different faculties also show different learning environments, for example, the unique context of each academic subject, classroom atmosphere, student-teacher relationship, and peer relationship. Previous research reports have shown that student's mental health is positively correlated with the classroom environment (Bordbar, Nikkar, Yazdani, \& Alipoor, 2011; Peters, 2013; Rania, Siri, Bagnasco, Aleo, \& Sasso, 2014; Turashvili \& Japaridze, 2012). Consistently, Yurayat and Chaikumpa (2020) have reported that students from the Faculty of Science show higher mental health status than students from Mahasarakham Business School and the Faculty of Humanities and Social Sciences. Students with poor mental health status and low happiness exhibit a high level of counseling needs; consequently, Mahasarakham Business School shows more needs to implement online counseling programs than Faculty of Science, Faculty of Engineering, College of Politics and Governance, and Faculty of Education. Furthermore, Jittanoon and Wungthanakorn (2018) have demonstrated that students from the Faculty of Science are happier and have more balance in life than students from the Faculty of Humanities and Social Sciences. This may be due to the fact that humanities and social sciences students exhibit lower self-esteem and self-satisfaction than science students.

Furthermore, other factors, including gender, age, and GPA, did not have an impact on the needs for the online 
counseling programs. Indeed, everybody can have stress or mental health problems regardless of being male or female. Consistent with previous findings, there is no significant evidence to indicate the relationship between gender and mental health of undergraduate students (Daraei, 2013; Thavorn, Pimroon, \& Thanoi, 2018); however, the nature of mental health problems might be different in each gender. Furthermore, the diversity of mental health problems is also linked with student's academic year. For example, first- and second-year students are in the adjusting mode to the changes in academic settings from the high school to university, and they tend to have the lower capability of managing with different learning environments (Durand-Bush, McNeill, Harding, \& Dobransky, 2015; Morales-Rodríguez, 2020; Plominski \& Burns, 2018). First-year university students might have problems with the adjustment to new environments, unfamiliar social settings, and different features of university teaching strategy, which are different from high school experience. Higher level students are preoccupied with more responsibility from school works, such as assignments, exams, and senior projects (Shahira et al., 2018). Regardless of the nature of student's problems, stress and anxiety can have an impact on many students. Moreover, the academic achievement did not show the relationship with mental health problems. Students with any GPA can have trouble in school or at home, and those problems can cause stress and drive students to seek counseling services.

\subsection{Prioritization of the Needs to Develop Online Counseling Program for Undergraduate Students}

The broad outcome of ranking the needs to develop an online counseling program among undergraduate students of Mahasarakham University indicated that our students displayed the needs on all four criteria, including characteristics of a suitable counselor, the application platform for online counseling, the characteristics of counselee, and therapeutic outcome after counseling. By ranking for the priority needs, the results showed that students placed both characteristics of counselor and online application as the first priorities for the development of online counseling programs. The subsequent priorities include characteristics of the counselee and therapeutic relationship, respectively. Indeed, the characteristics of a counselor are crucial factors to support and direct online counseling services. For example, they should acquire knowledge and skills in mental health counseling. They should also be able to use computer and internet communication equipment. Additionally, the potential counselor should have suitable personalities for counseling processes, such as emotional intelligence, kindness, credibility, the ability of relationship building, and confidentiality of clients. These characteristics are for either face-to-face sessions or online counseling programs. The counselor is a crucial factor that could lead to either success or failure in the outcome of counseling (Corey, 2006). Personal characteristics are also important for a good counselor, and they can be separated into four aspects, consisting of knowledge, practical skill, personality, and moral and ethical aspects (Yurayat, 2020). Normally, most counselees prefer a counselor who has a warm personality, credibility, and maintaining confidentiality. The counselor should have knowledge and competence as a professional expert. So, the counselees feel confident that their problems would be solved. Subsequently, they can manage to live their normal lives.

Internet platform for online counseling is also the first priority that university students emphasize. Online application for mental health counseling is the channel of communication that can provide the feelings of security and accessibility for the clients (or counselees), including 1) convenient accessibility of service, 2) flexibility of time and places, 3) reduction of traveling expenses, 4) anonymity or concealment of one's identity, and 5) being carefree from mental health stigma (S. Bastemur \& E. Bastemur, 2015; Centore \& Milacci, 2008; Jones \& Stokes, 2009; Rodda, 2017). They can also be confident on the security and confidentiality using a computer and other devices involved with online counseling service (Cipolletta \& Mocellin, 2018; Lindinger-Sternart \& Piazza, 2014). The characteristics of counselee as priority needs for implementation of online counseling were ranked as the second priority. Some individuals show the determination to solve their problems with perception of self-efficacy, capability in self-regulation, and understanding of self-help techniques. Furthermore, they hold the belief, attitudes, motivations, experiences, and expectations that are in such a positive way toward online counseling service (Liu, 2015; Ritterband et al., 2009; Teo et al., 2020). They should also have the knowledge and ability to use a computer and other internet communication devices for counseling (Cipolletta \& Mocellin, 2018; Richards \& Viganó, 2013; Tannous, 2017). In addition, the last priority of needs to develop an online counseling program was identified as the therapeutic relationship of online counseling. The therapeutic relationship is an important factor for treatment intervention (Richards \& Viganó, 2013). It is the process of corporation between counselor and counselee in order to assist and manage the counselee's problems (Cook \& Doyle, 2002), including relationship building, maintaining a relationship during a counseling session, and terminating the relationship after the counseling period. The counselor provides advice, feedback, emotional transference, and two-way interaction throughout an online counseling process (Barak et al., 2009; Colbow, 2013; Guay et al., 2017). 


\section{Conclusion}

The results of this research show that undergraduate students of Mahasarakham University need an online counseling program. They consider that online counseling could reduce the limitations of getting face to face counseling services, meet the needs. They don't need to reveal their true identity that feels the security, and convenience to access the online counseling service. Therefore, online counseling should be developed and support with an effective internet system to be another channel for increasing psychological well-being and managing the challenge complexed problems' life in university effectively.

\section{Acknowledgments}

This research project is financially supported by Mahasarakham University.

\section{References}

Al-Krenawi, A., \& Graham, J. R. (2000). Culturally sensitive social work practice with Arab clients in mental health settings. Health \& Social Work, 25(1), 9-22. https://doi.org/10.1093/hsw/25.1.9

Al-Krenawi, A., Graham, J. R., Al-bedah, E., Kadri, H. M., \& Sehwail, M. A. (2009). Cross-national comparison of Middle Eastern university students: Help-seeking behaviors, attitudes toward helping professionals, and cultural beliefs about mental health problems. Community Mental Health Journal, 45, 26-36. https://doi.org/10.1007/s10597-008-9175-2

Amichai-Hamburger, Y. (2017). Internet psychology: The basics. New York, NY: Routledge. https://doi.org/10.4324/9781315622163

Arnett, J. J. (2004). Emerging adulthood: The winding road from the late teens through the twenties. New York, NY: Oxford University Press.

Auerbach, R. P., Alonso, J., Axinn, W., Cuijpers, P., Ebert, D., Green, J., . . . Bruffaerts, R. (2016). Mental disorders among college students in the World Health Organization World Mental Health Surveys. Psychological Medicine, 46(14), 2955-2970. https://doi.org/10.1017/S0033291716001665

Auerbach, R. P., Mortier, P., Bruffaerts, R., Alonso, J., Benjet, C., Cuijpers, P., . . Kessler, R. C. (2018). WHO World Mental Health Surveys International College Student Project: Prevalence and distribution of mental disorders. Journal of Abnormal Psychology, 127(7), 623-638. https://doi.org/10.1037/abn0000362

Barak, A., Klein, B., \& Proudfoot, J. G. (2009). Defining internet-supported therapeutic interventions. Annals of Behavioral Medicine, 38(1), 4-17. https://doi.org/10.1007/s12160-009-9130-7

Bastemur, S., \& Bastemur, E. (2015). Technology Based Counseling: Perspectives of Turkish Counselors. Procedia-Social and Behavioral Sciences, 176, 431-438. https://doi.org/10.1016/j.sbspro.2015.01.493

Bolier, L., Ketelaar, S. M., Nieuwenhuijsen, K., Smeets, O., Gärtner, F. R., \& Sluiter, J. K. (2014). Workplace mental health promotion online to enhance well-being of nurses and allied health professionals: A cluster-randomized controlled trial. Internet Interventions, 1(4), 196-204. https://doi.org/10.1016/j.invent.2014.10.002

Bordbar, F. T., Nikkar, M., Yazdani, F., \& Alipoor, A. (2011). Comparing the psychological well-being level of the students of Shiraz Payame Noor University in view of demographic and academic performance $\begin{array}{lllll}\text { variables. Procedia-Social and Behavioral } & \text { Sciences, }\end{array}$ https://doi.org/10.1016/j.sbspro.2011.11.290

Centore, A., \& Milacci, F. (2008). A study of mental health counselors' use of and perspectives on distance counseling. Journal of Mental Health Counseling, 30(3), 267-282. https://doi.org/10.17744/mehc.30.3.q871r684n863u75r

Cheung, R., O’Donnell, S., Madi, N., \& Goldner, E. (2017). Factors associated with delayed diagnosis of mood and/or anxiety disorders. Health Promotion and Chronic Disease Prevention in Canada, 37(5), 137-148. https://doi.org/10.24095/hpcdp.37.5.02

Cipolletta, S., \& Mocellin, D. (2018). Online counseling: An exploratory survey of Italian psychologists' attitudes towards new ways of interaction. Psychotherapy Research, 28(6), 909-924. https://doi.org/10.1080/10503307.2016.1259533

Colbow, A. J. (2013). Looking to the future: Integrating telemental health therapy into psychologist training. Training and Education in Professional Psychology, 7(3), 155-165. https://doi.org/10.1037/a0033454

Cook, J. E., \& Doyle, C. (2002). Working alliance in online therapy as compared to face-to-face therapy: 
Preliminary results. CyberPsychology \& Behavior, 5(2), 95-105. https://doi.org/10.1089/109493102753770480

Corey, G. (2006). Theory \& practice of group counseling (7th ed.). Monterey, CA: Brooks/Cole Pub. Co.

Daraei, M. (2013). Social correlates of psychological well-being among undergraduate students in Mysore City. Social Indicators Research, 114(2), 567-590. https://doi.org/10.1007/s11205-012-0162-1

Davies, E. B., Morriss, R., \& Glazebrook, C. (2014). Computer-delivered and web-based interventions to improve depression, anxiety, and psychological well-being of university students: A systematic review and meta-analysis. Journal of Medical Internet Research, 16(5), e130. https://doi.org/10.2196/jmir.3142

Department of Mental Health reveals 3 million Thais suffer from depression. (2008, September 18). Bangkok Post. Retrieved from http://www.bangkokbiznews.com/2008/06/11/news_265601.php

Department of Mental Health. (2019). The Department of Mental Health reveals Thai adolescents to consult the Mental Health Hotline 1323. Retrieved from http://www.prdmh.com/news/1472.html

Durand-Bush, N., McNeill, K., Harding, M., \& Dobransky, J. (2015). Investigating stress, psychological well-being, mental health functioning, and self-regulation capacity among university undergraduate students: Is this population optimally functioning? Canadian Journal of Counselling and Psychotherapy, 49(3), 253-274. Retrieved from https://cjc-rcc.ucalgary.ca/article/view/61066

Ebert, D. D., Cuijpers, P., Muñoz, R. F., \& Baumeister, H. (2017). Prevention of mental health disorders using internet-and mobile-based interventions: A narrative review and recommendations for future research. Frontiers Psychiatry, 8(116), 1-16. https://doi.org/10.3389/fpsyt.2017.00116

Eisenberg, D., Golberstein, E., \& Hunt, J. B. (2009). Mental health and academic success in college. The B.E. Journal of Economic Analysis \& Policy, 9(1), 1-40. https://doi.org/10.2202/1935-1682.219

Evans, N. J., Forney, D. S., Guido, F. M., Patton, L. D., \& Renn, K. A. (2009). Student development in college: Theory, research, and practice (2nd ed.). San Francisco, CA: Jossey-Bass.

Fenichel, M., Suler, J., Barak, A., Zelvin, E., Jones, G., Munro, K., ... Walker-Schmucker, W. (2002). Myths and realities of online clinical work. CyberPsychology \& Behavior, 5(5), 481-497. https://doi.org/10.1089/109493102761022904

Fishbein, M., \& Ajzen, I. (2000). The prediction of behavior from attitudinal and normative variables. In E. T. Higgins, \& A. W. Kruglanski (Eds.), Key reading in social psychology. Motivational science: Social and personality perspectives (pp. 177-190). New York, NY: Psychology Press.

Fusikul, N. (2012). An action research on online counseling (Master's thesis, Chiang Mai University, ChiangMai, Thailand). Retrieved from http://cmuir.cmu.ac.th/handle/6653943832/23126

Gander, F. (2017). Positive Psychology interventions: Are they effective for increasing well-being? In J. Marcionetti, L. Castelli, \& A. Crescentini (Eds.), Well-being in education systems: Conference Abstract Book (pp. 8-12). Firenze: Hogrefe.

Goldman-Mellor, S. J., Caspi, A., Harrington, H., Hogan, S., Nada-Raja, S., Poulton, R., \& Moffitt, T. E. (2014). Suicide attempt in young people: a signal for long-term health care and social needs. JAMA Psychiatry, 71(2), 119-127. https://doi.org/10.1001/jamapsychiatry.2013.2803

Guay, C., Auger, C., Demers, L., Mortenson, W. B., Miller, W. C., Gélinas-Bronsard, D., \& Ahmed, S. (2017). Components and outcomes of internet-based interventions for caregivers of older adults: Systematic review. Journal of Medical Internet Research, 19(9), e313. https://doi.org/10.2196/jmir.7896

Harris, B., \& Birnbaum, R. (2015). Ethical and legal implications on the use of technology in counselling. Clinical Social Work Journal, 43(2), 133-141. https://doi.org/10.1007/s10615-014-0515-0

Heflinger, C. A., \& Hinshaw, S. P. (2010). Stigma in child and adolescent mental health services research: Understanding professional and institutional stigmatization of youth with mental health problems and their families. Administration and Policy in Mental Health, 37(1-2), 61-70. https://doi.org/10.1007/s10488-010-0294-z

Hootsuite, \& We Are Social. (2020, Febuary 18). Digital 2020: Thailand. Retrieved from https://datareportal.com/reports/digital-2020-thailand

Hyun, J., Quinn, B., Madon, T., \& Lustig, S. (2006). Graduate student mental health: Needs assessment and utilization of counseling services. Journal of College Student Development, 47(3), 247-266. 
https://doi.org/10.1353/csd.2006.0030

Ibrahim, A. K., Kelly, S. J., Adams, C. E., \& Glazebrook, C. (2013). A systematic review of studies of depression prevalence in university students. Journal of Psychiatric Research, 47(3), 391-400. https://doi.org/10.1016/j.jpsychires.2012.11.015

Ishii, T., Tachikawa, H., Shiratori, Y., Hori, T., Aiba, M., Kuga, K., \& Arai, T. (2018). What kinds of factors affect the academic outcomes of university students with mental disorders? A retrospective study based on medical records. Asian Journal of Psychiatry, 32, 67-72. https://doi.org/10.1016/j.ajp.2017.11.017

Jittanoon, P., \& Wungthanakorn, S. (2018). Harmony in life of University Students, Southern Thailand. Songklanagarind Journal of Nursing, 38(4), 103-113. Retrieved from https://he02.tci-thaijo.org/index.php/nur-psu/article/view/163916

Jones, G., \& Stokes, A. (2009). Online counselling: A handbook for practitioners. Basingstoke, UK: Palgrave Macmillan. https://doi.org/10.1007/978-0-230-23085-9

Knaevelsrud, C., \& Maercker, A. (2006). Does the quality of the working alliance predict treatment outcome in online psychotherapy for traumatized patients? Journal of Medical Internet Research, 8(4), e31. https://doi.org/10.2196/jmir.8.4.e31

Krupnick, J. L., Sotsky, S. M., Simmens, S., Moyer, J., Elkin, I., Watkins, J., \& Pilkonis, P. A. (1996). The role of the therapeutic alliance in psychotherapy and pharmacotherapy outcome: Findings in the National Institute of Mental Health Treatment of Depression Collaborative Research Program. Journal of Consulting and Clinical Psychology, 64(3), 532-539. https://doi.org/10.1037/0022-006X.64.3.532

Lambert, M. J., \& Barley, D. E. (2001). Research summary on the therapeutic relationship and psychotherapy outcome. Psychotherapy: Theory, Research, Practice, Training, 38(4), 357-361. https://doi.org/10.1037/0033-3204.38.4.357

Li, L. P., Jaladin, R. A. M., \& Abdullah, H. S. (2013). Understanding the two sides of online counseling and their ethical and legal ramifications. Procedia-Social and Behavioral Sciences, 103, 1243-1251. https://doi.org/10.1016/j.sbspro.2013.10.453

Lindinger-Sternart, S., \& Piazza, N. (2014). Major ethical considerations and technological challenges related to distance professional services. International Journal of Social Science Studies, 3(1), 104-110. https://doi.org/10.11114/ijsss.v3i1.620

Liu, S. (2015). Hypertension treatment using an internet-based lifestyle intervention (Doctoral Dissertation). Retrieved from http://hdl.handle.net/1807/71045

Mallen, M. J., \& Vogel, D. L. (2005). Introduction to the major contribution: Counseling psychology and online counseling. The Counseling Psychologist, 33(6), 761-775. https://doi.org/10.1177/0011000005278623

Mallen, M., Day, S., \& Green, M. (2003). Online versus face-to-face conversation: An examination of relational and discourse variables. Psychotherapy: Theory, Research, Practice, Training, 40(1-2), 155-163. https://doi.org/10.1037/0033-3204.40.1-2.155

Martin, D. J., Garske, J. P., \& Davis, M. K. (2000). Relation of the therapeutic alliance with outcome and other variables: A meta-analytic review. Journal of Consulting and Clinical Psychology, 68(3), 438-450. https://doi.org/10.1037/0022-006X.68.3.438

Mendes-Santos, C., Weiderpass, E., Santana, R., \& Andersson, G. (2019). A guided internet-delivered individually-tailored ACT-influenced cognitive behavioural intervention to improve psychosocial outcomes in breast cancer survivors (iNNOVBC): Study protocol. Internet Interventions, 17, 100236. https://doi.org/10.1016/j.invent.2019.01.004

Mitchell, J., Vella-Brodrick, D., \& Klein, B. (2010). Positive psychology and the internet: A mental health opportunity. E-Journal of Applied Psychology, 6(2), 30-41. https://doi.org/10.7790/ejap.v6i2.230

Morales-Rodríguez, F. M., Espigares-López, I., Brown, T., \& Pérez-Mármol, J. M. (2020). The relationship between psychological well-being and psychosocial factors in university students. International Journal of Environmental Research and Public Health, 17(13), 4778. https://doi.org/10.3390/ijerph17134778

Muir, S. D., de Boer, K., Thomas, N., Seabrook, E., Nedeljkovic, M., \& Meyer, D. (2020). Videoconferencing psychotherapy in the public sector: Synthesis and model for implementation. JMIR Mental Health, 7(1), e14996. https://doi.org/10.2196/14996 
Navarro, P., Bambling, M., Sheffield, J., \& Edirippulige, S. (2019). Exploring young people's perceptions of the effectiveness of text-based online counseling: Mixed methods pilot study. JMIR Mental Health, 6(7), e13152. https://doi.org/10.2196/13152

Niederkrotenthaler, T., Tinghög, P., Alexanderson, K., Dahlin, M., Wang, M., Beckman, K., . . . Mittendorfer-Rutz, E. (2014). Future risk of labour market marginalization in young suicide attempters--A population-based prospective cohort study. International Journal of Epidemiology, 43(5), 1520-1530. https://doi.org/10.1093/ije/dyu155

Office of Policy and Strategic Affairs, Electronic Transactions Development Agency, Ministry of Digital Economy and Society. (2020). Thailand internet user behavior 2019. Retrieved from https://www.etda.or.th/th/UsefulResource/publications/Thailand-Internet-User-Behavior-2019_EN.aspx

Peters, M. L. (2013). Examining the relationships among classroom climate, self-efficacy, and achievement I undergraduate mathematics: A multi-level analysis. International Journal of Science and Mathematics Education, 11(2), 459-480. https://doi.org/10.1007/s10763-012-9347-y

Plominski, A. P., \& Burns, L. R. (2018). An investigation of student psychological wellbeing: Honors versus nonhonors undergraduate education. Journal of Advanced Academics, 29(1), 5-28. https://doi.org/10.1177/19322 02X17735358

Proudfoot, J., Klein, B., Barak, A., Carlbring, P., Cuijpers, P., Lange, A., . . Andersson, G. (2011). Establishing guidelines for executing and reporting Internet intervention research. Cognitive Behaviour Therapy, 40(2), 82-97. https://doi.org/10.1080/16506073.2011.573807

Rania, N., Siri, A., Bagnasco, A., Aleo, G., \& Sasso, L. (2014). Academic climate, well-being and academic performance in a university degree course. Journal of Nursing Management, 22(6), 751-760. https://doi.org/10.1111/j.1365-2834.2012.01471.x

Richards, D., \& Tangney, B. (2008). An informal online community for student mental health at university: A preliminary investigation. British Journal of Guidance and Counselling, 36(1), 81-97. https://doi.org/10.1080/03069 880701715671

Richards, D., \& Viganó, N. (2013). Online counseling: A narrative and critical review of the literature. Journal of Clinical Psychology, 69(9), 994-1011. https://doi.org/10.1002/jclp.21974

Ritterband, L. M., Thorndike, F. P., Cox, D. J., Kovatchev, B. P., \& Gonder-Frederick, L. A. (2009). A behavior change model for internet interventions. Annals of Behavioral Medicine, 38(1), 18-27. https://doi.org/10.1007/s12160-009-9133-4

Rodda, S. N. (2017). Online counselling for problem gambling: An analysis of client and session characteristics (Doctoral Dissertation, Eastern Health Clinical School, Faculty of Medicine, Nursing and Health Science, Monash University, Australia). Retrieved from https://doi.org/10.4225/03/58ae44cfc410b

Royal College of Psychiatrists. (2011). Mental health of students in higher education. London: Royal College of Psychiatrists.

Seechaliao, T., \& Rungrueng, C. (2016). Using Social Media to Improve Undergraduate' Mental Health. International Journal of Social Science and Humanity, 6(12), 948-951. https://doi.org/10.18178/ijssh.2016.V6.779

Shahira, M. N., Hanisshya, H., Lukman, Z. M., Normala, R., Azlini, C., \& Kamal, M. Y. (2018). Psychological well-being among university students in Malaysia. International Journal of Research and Innovation in Social Science (IJRISS), 2(12), 133-137. $\quad$ Retrieved from https://www.researchgate.net/publication/337494154

Slouka, M. (1995). War of the worlds: Cyber-space and the high-tech assault on reality. New York, NY: Basic Books.

Stoll, J., Müller, J. A., \& Trachsel, M. (2020). Ethical issues in online psychotherapy: A narrative review. Frontiers in Psychiatry, 10(993), 1-16. https://doi.org/10.3389/fpsyt.2019.00993

Sukmawati, I., Ardi, Z., Ifdil, I., \& Zikra, Z. (2019). Development and validation of acceptability of mental-health mobile app survey (AMMS) for android-based online counseling service assessment. Journal of Physics: Conference Series, 1339(012124), 1-7. https://doi.org/10.1088/1742-6596/1339/1/012124

Tannous, A. (2017). Perceptions towards online counseling among university of Jordan students. Modern Applied Science, 11(12), 68-76. https://doi.org/10.5539/mas.v11n12p68 
Teh, L. A., Acosta, A. C., Hechanova, M. R. M., Garabiles, M. R., \& Alianan Jr, A. S. (2014). Attitudes of psychology graduate students toward face-to-face and online counseling. Philippine Journal of Psychology, 47(2), 65-79. Retrieved from https://www.pap.ph/file/pjp/pjp2014-47-2-pp65-97-tehacostahechanovagarabilesalianan-attitudes_of_psych ology_graduate_students_t.pdf

Teo, T., Shi, W., Huang, F., \& Hoi, C. K. W. (2020). Intergenerational differences in the intention to use psychological cybercounseling: A Chinese case study. Patient Education and Counseling, 103(8), 1615-1622. https://doi.org/10.1016/j.pec.2020.02.035

Thavorn, T., Pimroon, S., \& Thanoi, W. (2018). Correlated factors of psychological well-being among high school students. Nursing Science Journal of Thailand, 36(3), 59-70. Retrieved from https://he02.tci-thaijo.org/index.php/ns/article/view/146982

Turashvili, T., \& Japaridze, M. (2012). Psychological well-being and its relation to academic performance of students in Georgian context. Problems of Education in the 21st Century, 49, 73-80. Retrieved from http://www.scientiasocialis.lt/pec/node/803

Verger, P., Guagliardo, V., Gilbert, F., Rouillon, F., \& Kovess-Masfety, V. (2009). Psychiatric disorders in students in six French universities: 12-month prevalence, comorbidity, impairment and help-seeking. Social Psychiatry and Psychiatric Epidemiology, 45(2), 189-199. https://doi.org/10.1007/s00127-009-0055-z

Vongtangswad, S. (2016). The effect of individual existential-humanistic online counseling on wellness of undergraduates with neuroticism (Doctoral dissertation, Chulalongkorn University, Bangkok, Thailand). Retrieved from http://cuir.car.chula.ac.th/handle/123456789/54881

Wang, P. S., Berglund, P., Olfson, M., Pincus, H. A., Wells, K. B., \& Kessler, R. C. (2005). Failure and delay in initial treatment contact after first onset of mental disorders in the National Comorbidity Survey Replication. Archives of General Psychiatry, 62(6), 603-613. https://doi.org/10.1001/archpsyc.62.6.603

Watkins R., Meiers, M., \& Visser, Y. L. (2012). A guide to assessing needs: Essential tools for collecting information, making decisions, and achieving development results. Washington DC: The World Bank. https://doi.org/10.1596/978-0-8213-8868-6

Watkins, R., \& Kaufman, R. (1996). An update on relating needs assessment and needs analysis. Performance Improvement, 35(10), 10-13. https://doi.org/10.1002/pfi.4170351005

Wiratchai, N. (2005). Interesting Statistics. Bangkok: Chulalongkorn University Publication.

Wongwanich, S. (2005). Needs Assessment Research. Bangkok: Chulalongkorn University Publisher.

World Health Organization [WHO]. (2008). Global tuberculosis control: Surveillance, planning, financing: WHO report 2008. Geneva: World Health Organization. Retrieved from https://apps.who.int/iris/handle/10665/43831

Yamane, T. (1967). Elementary sampling theory. Englewood Cliffs, N.J., Prentice-Hall.

Yurayat, P., \& Chaikumpa, K. (2020). A study of psychological well-being of Mahasarakham University Students. Mahasarakham: Mahasarakham University.

Yurayat, P. (2020). Group consultation: Principles, concepts, and theories (2nd ed.). Mahasarakham: Apichat Publication.

Zainudin, Z., \& Yusop, Y. M. (2018). Client's satisfaction in face-to-face counselling and cyber counseling approaches: A comparison. The International Journal of Academic Research in Business and Social Sciences, 8(3), 677-684. https://doi.org/10.6007/ijarbss/v8-i3/3992

\section{Copyrights}

Copyright for this article is retained by the author(s), with first publication rights granted to the journal.

This is an open-access article distributed under the terms and conditions of the Creative Commons Attribution license (http://creativecommons.org/licenses/by/4.0/). 